\title{
IDLE Challenges: Playing Digital Games?
}

\author{
Muhammad Najmussaqib Diya Alhaq ${ }^{1}$, Nur Arifah Drajati ${ }^{2}$, Agus Wijayanto 3 \\ DOI: $10.35445 /$ alishlah.v13i1.440
}

\begin{tabular}{l}
\hline Article Info \\
\hline Keywords: \\
COVID-19 \\
Digital games \\
English Foreign Language \\
Informal digital learning
\end{tabular}

Abstract

The purpose of this research is to examine the challenges faced by the learner and the activities they undertake concerning informal digital learning of English (IDLE) implementation in the English as foreign language (EFL) context. The impact of the COVID-19 on the education sector feels very challenging. Especially in EFL learning at the high/secondary school level, it is crucial since the skills are needed to support such level students' more complex need. It leads many experts to find the formal model's best alternative: playing digital games as IDLE. However, the current indications showed various challenges in the efforts of implementing IDLE within an academic context. As part of a more extensive sequential qualitative mixed-method study, seven high school students from various Indonesia parts were interviewed. From the findings, it is discovered that there were still some challenges regarding the implementation of IDLE in an academic context: physical and behavioural assumptions, dealing with the growth of physical and behavioural effect misconception and logical fallacy within the community; communal judgment, the a priori assumption of 'gaming stereotype' which massively wide-spread; and, technical challenges, regarding the implemental availability of the contemporary learning model. It is also recommended that finding solutions to these challenges requires many parties' involvement. It is due to some of the challenges were fundamentals. It is expected that many parties' involvement will make the resulting efforts to be a holistic solution.

\begin{abstract}
Abstrak
Tujuan dari penelitian ini adalah untuk mengusut tantangan yang dihadapi oleh pembelajar serta aktivitas yang mereka lakukan dalam kaitannya dengan pengimplementasian pembelajaran Bahasa Inggris informal berbasis digital (IDLE) pada konteks pembelajaran Bahasa Inggris sebagai bahasa asing (EFL). Imbas dari penyebaran COVID-19 terhadap sektor pendidikan terasa begitu menantang. Khususnya dalam pembelajaran EFL pada jenjang sekolah menengah atas, hal ini dirasa lebih krusial dikarenakan keterampilan pada jenjang tersebut diperlukan oleh para siswa untuk menghadapi kebutuhan yang lebih kompleks. Fenomena ini mendorong para ahli untuk mencari alternatif terbaik guna menggantikan model pembelajaran formal, yaitu: bermain gim digital sebagai bagian dari IDLE. Meski begitu, indikasi yang ada menunjukan keberadaan berbagai tantangan dalam upaya pengimplementasian IDLE kedalam konteks akademis. Sebagai bagian dari studi metode campuran sekuensial dominan kualitatif, tujuh siswa sekolah
\end{abstract}

\footnotetext{
${ }^{1}$ Universitas Sebelas Maret, Surakarta, Indonesia

Email: artazgang@student.uns.ac.id

2 Universitas Sebelas Maret, Surakarta, Indonesia

Email: drajatinur@gmail.com

3 Universitas Muhammadiyah Surakarta, Surakarta, Indonesia

Email: agus.abdn@gmail.com

Vol.13 (1) June, 2021

Received: March 14, 2021; Received in revised form: March 21, 2021; Accepted: March 22, 2021; Available online: March 30, 2021

This is an open access article under a Creative Commons Attribution-NonCommercial-ShareAlike 4.0 International License
} 


\begin{abstract}
menengah atas dari berbagai belahan Indonesia di wawancara. Dari temuan yang ada diketahui bahwa masih terdapat beberapa tantangan yang berkaitan dengan penerapan IDLE pada konteks akademis, yaitu: tantangan asumsi jasmani dan perilaku, berurusan dengan tumbuhnya miskonsepsi dampak fisik dan psikis serta kekeliruan logika masyarakat; anggapan komunal, asumsi apriori tentang 'stereotip gim' yang sudah tersebar luas secara masif; dan teknis, mengenai ketersediaan implementasi model pembelajaran kontemporer. Disarankan dalam upaya pencarian solusi pemecahan berbagai tantangan ini, agar dapat dilibatkannya berbagai pihak. Diharapkan dengan melibatkan banyak pihak, upaya yang dihasilkan akan dapat menjadi sebuah solusi yang bersifat holistik.
\end{abstract}

\title{
INTRODUCTION
}

With the outbreak of the nowadays COVID-19 pandemic, the education sector is facing quite a challenge. Education practitioners and academicians must switch to a more contemporary way of online teaching and learning by involving advanced technologies (Unwin et. al, 2020) rather than preserving the conventional in-class education method. Such limitation in the educational sector is considered significant during the pandemic to suppress the virus spread (Jackson et al., 2013).

The existing curriculum was never before be prepared for such a pandemic scenario where formal education completely abandoned the in-class teaching and learning and shifted to the informal learning outside-the-classroom domain (Oyedotun, 2020). Nonetheless, many people, especially parents, still doubt the effectiveness of such transfer of learning models. Most of them believed that informal teaching and learning is not as effective as formal ones (Dong et al., 2020). This assumption contradicts the experts' findings which stated that informal learning is crucial to be included in a holistic formal education process (Hirschel \& Fritz, 2013).

In the case of the English subject, the encounter turns to be more challenging since the students of English as Foreign Language (EFL) need to train their English continuously to prepare the encounter of more significant future challenges (Peterson, 2016; Sintema, 2020; Syauqi et al., 2020) - making this school level deserve more attention. In response to this, one of the emerging solutions is Informal Digital Learning of English or also known as IDLE. It may be the preeminent solution to the various pandemic challenges, which requires integration between the latest digital media empowerment in the context of alternative formal learning (Lee, 2019a; Lee, 2019b; Lee \& Lee, 2019).

The IDLE model is firmly rooted in a concept that many experts have previously introduced in the field of informal learning outside-the-classroom (Benson \& Reinders, 2011; Sundqvist, 2011; Lee, 2019a). Regarding its concepts, Lee (2019a) then added a slightly different definition for IDLE as an informal learning model that also emphasizes digital media utilization. He also believed that this model is part of the computer-assisted language learning (CALL) approach and firmly correlated with mobile-assisted language learning (MALL) studies. Experts mentioned several media which may be used within the IDLE model: social media, speech-to-text software, blogs, online communities, MP3s especially English songs, websites especially YouTube, web apps, movies, online programs, and digital games (Lee, 2019a; Lee \& Drajati, 2019; Lee \& Hsieh, 2019; Lee \& Lee, 2019).

In implementing those various IDLE media within an academic context, digital games face the most challenges. It was mainly felt by their players (the gamers), who were also happened to be school students. It is due to several factors, which other IDLE media do not seem to have experienced, for the instances: the world institution's (such as the World Health Organization) reinforcement which cornered the gaming tendency into a category of disorders (Entwistle et al., 2020); or the general belief which sees the gaming activities as destructive behaviour and contradicts any educational purposes (Adžić et al., 2021).

Under the concept put forward by Lai et al. (2012), the proper type of digital games that suit language learning is called a commercial of the shelf (COTS) game. It refers to a type of game widely 
traded on the market and is explicitly intended for amusement purposes only. They believed that the COTS game had already been implemented on many occasions concerning the language learning advancements of this century, especially regarding its textual basis characteristics.

Many scientific evidence and findings proved that digital games are constructive activities, primarily upon academic matters. Contrary to the statement of those factors, Alhaq et al. (2020) discovered that 'gamer' students exposed the existence of self-efficacy in learning English and could be reflected as an effective autonomous learner of the English language. Moreover, Ashraf et al. (2014) also believed that playing online games is an effective media for learning English vocabularies.

On that basis, to get a concrete picture of the challenges in implementing IDLE (especially video games) in the EFL context, it is necessary to have a description of the obstacles experienced by gamers in the field so far. Such findings are expected to help practitioners, academicians, and stakeholders determine the best strategies and positions for informal learning within the curriculum that consider the pandemic scenario.

The findings of several studies have shown the challenges faced by gamers and the activities they carry out: Entwistle et al. (2020) emphasized the issue of WHO's move in categorizing excessive gaming activity as a disorder related to levels of destructive addiction. From the result, they believe that digital games are not addictive. Furthermore, Adžić et al. (2021) raised the general assumption that digital games have a degradative impact on educational practices and outcomes. Their findings suggested that the 'gamer' students could effectively allocate and balance their time between playing the game and studying. Thus they still earned outstanding academic achievement.

The various research findings showed some of the challenges faced by the gamer community, especially students. Likewise, those two studies also have a common thread that emphasizes how gaming activities are treated today. This research would still examine the challenges faced by gamers and the activities they undertake. However, the most contrasting differences were: (1) the theoretical point of view used, where in these research, digital games are seen through the framework of the IDLE learning model (Lee, 2019a; Lee \& Drajati, 2019; Lee \& Hsieh, 2019; Lee \& Lee, 2019); (2) the context that highlight the implications for the students' informal learning process in the pandemic era, as an altered form of formal learning models.

From that gap, we conducted this research to examine the challenges faced by gamer students and their activities regarding IDLE implementation in the EFL context. It was carried out based on the increasing need for a solution that can be used in responding to various challenges of the education sector during the outbreak. Researchers see a model that may act as the answer to these needs: the IDLE. However, it is unfortunate that this model is not widely known and still needs a lot of adjustments. The use of the English model's informal digital learning is an innovation that has not been considered much, especially in Indonesia. This research supports various previous research findings, provides a new picture of the existence of a potential learning model, and seeks to provide an overview of things that need to be considered in the application of digital media-based informal English learning.

\section{METHODS}

This research was part of a more extensive sequential qualitative mixed-method study, which examines IDLE challenges within the EFL context and several academic domains of EFL students with digital gaming experiences. The study collected qualitative and quantitative data by employing several instruments. However, in particular, according to what will be discussed in this research paper, we only employed a research question: "Do the students face any challenges in playing games as IDLE implementation?"

We started the data collection from the primary respondents of our previous researches (convenience sampling). Initially, there were ten primary respondents that we further followed up. 
From those gamer students, 3 of them believed that they had not experienced any challenge in playing games as a form of IDLE. There were only 7 of them who experienced some challenges. Thus, we conducted a further in-depth guided interview. Those students came from 6 different high schools, with ages 16 (11 grade) and 17 (12 grade). Through a guided interview session via WhatsApp calls, we ask them regarding the challenges of playing the digital game as IDLE. The guided interview questions regarding the discussion of this research paper were revolving around the topic: "Do you encounter any challenges in playing games as a form of IDLE?" The indirectly guided interview sessions were recorded and saved with each respondent's permission for academic and research purposes. Overall, this phase was done in 10 days, from July 10 to 20, 2020.

To answer the research questions, the findings from the interview sessions were analyzed suit with Johnson and Christensen's (2019) techniques in qualitative analysis: the recording of the respondents' statement was transcribed verbatim; then we coded and categorized the transcription content into some themes; finally, those themes would be used to identifying the relationship of the findings and drawing the result of the study.

\section{FINDINGS AND DISCUSSION}

From the interview result, we discovered that most of the students (70\%) were facing various challenges in playing the digital game as IDLE activities. Their responses then were classified into 3 categories:

\section{The physical and behavioural assumptions challenges}

Some of the respondents said several things which we considered as physical and behavioural assumptions challenges. It is concluded based on several respondents' statements: they assumed that playing games might affect their physical and behavioural conditions for some amount of time. Regarding the physical assumption challenges, it was taken from the statement of Respondent 3, who stated:

"...Yeah, actually it (playing games) has positives and negatives impact... for the negative impact, yeah... 'because, sometimes I am playing games too long... and also, maybe because I often hold a cellphone or laptop for such extended period, so... made my eyesight worse..." (Respondent 3. Interview. July 12 2020)

Moreover, Respondent 7 also assumed the effect of playing video games on her behavioural and physical condition. She said:

"Especially for me, I often play [battle royal shooting game], a match of it can take 20-15 minutes... Moreover, sometimes, I took more than one match per session. Sometimes my parents ask me not to play too often, they say it may sore my eyesight or something... it also often made me sleep so late ... sometimes I got little dizzy from staring at the cellphone screen too long..." (Respondent 7. Interview. July 19 2020)

Their statements showed a challenge regarding the assumptions that digital games might affect physical conditions. A growing notion within the community believed that digital gaming activities might directly affect the physical condition. We believe that it is a logical fallacy that is already firmly entrenched in society. The truth is, it is not digital games that affect the condition of the body, but incorrect patterns of digital device usage.

Several kinds of research believed that some digital devices might directly affect the physical condition of their users. For example, Fernández et al. (2018) stated that mobile phones might expose some radiation on the human body, especially for children since younglings tend to absorb more. Thus, they recommended taking certain precautionary steps to eliminate mobile phones exposures, such as reducing the time of usage or not putting it too close to the limb. Moreover, Bhargava et al., 's (2019) also believed that the mobile phone's radiation exposures could be reduced by giving distances between the device and the body part. Hence, it was much recommended to not put the phone directly to the head when calling. 
Those researches were only several examples that discussed the effect of misused attempts of digital devices. From their findings, it can be suggested that everyone, not just the gamers, can get a negative physical impact from the digital devices if they use them excessively and improperly. It was a wrong thing if people assumed that digital games are the one which directly giving a negative physical impact.

It was also confirmed from the respondents' statement above that they got a negative physical impact because of the devices' excessive usage. Therefore, that is the first challenge for IDLE practitioners, i.e., clarifying the wild assumptions of informal digital learning's negative physical effect, especially digital games. It is significant so that digital games are not always blamed by society for something that is not what it should be.

It does not mean that digital games do not contribute to the wrong usage patterns of digital devices. It can also be seen from the statements above that digital gaming behaviour let them use the devices excessively, even made them lack sleep. This is a fact, which is also confirmed by Shi et al. (2019). They believed that digital gaming behaviour negatively affects the self-care needs fulfilment of the gamers, such as lack of sleep, less eat, and seldom bath.

It can be seen that the lack of self-control and ignorance regarding time spent measurement for playing are some of the gamers' significant problems. Most of them cannot limit themselves when playing games, and some also do not know the appropriate time amount for playing. That is the second challenge for IDLE practitioners in implementing the digital game as IDLE, i.e. how to issue the correct self-control practices and a proper 'gaming dosage', so that people can maximize the benefit obtained.

\section{The communal judgment challenges}

Most of the respondents said several things which we considered communal judgment challenges. This is taken from some respondents who believed that parents' control of digital gaming sometimes or often hindered them from playing. Also, many of them stated that the environment amongst them viewed the digital games as a negative activity without any benefits.

Regarding the parents' control and their negative belief, the statement of Respondent 7 before also reflected the issue, while also there was a statement from Respondent 8: "...In, playing games? ...My parents always remind me not to play games too often, so I could be more focused on my study..." (Respondent 8. Interview. July 20 2020). Moreover, Respondent 6 also stated the view of her environment upon digital gaming. She said that: "...yes, it (challenges in playing game) is often like that, people often said that it (playing game) has no benefit..." (Respondent 6. Interview. July 19 2020).

From those statements, it can be seen that there was a challenge for digital gaming as IDLE, which take shape as a priori assumptions amongst the community. We called it "Gaming Stereotype": the assumption that the digital game and its playing activities do not contribute anything too academic matters, especially those related to the students' cognitive domain development. This phenomenon seemed to appear in many parts of the world since some studies confirmed the same concepts: Entwistle et al. (2020) said that the move of WHO in determining the excessive playing of digital games as a form of addictive disorder were based on a priori assumption; Adžić et al. (2021) said that media has a major role in 'campaigning' the bad reputation of digital games, as well as reading comics and listening Rock music; Dong et al. (2020) discovered that parents, in general, had negative belief upon the informal learning and more prefer the conventional formal method of inclass teaching and learning.

Those are of course an assumption which contradicts with many scientific findings regarding the potentiality of IDLE, primarily digital gaming, within EFL context (Adžić et al., 2021; Alhaq et al., 2020; Hirschel \& Fritz, 2013; Lee, 2019a; Lee, 2019b; Lee \& Drajati, 2019; Lee \& Hsieh, 2019; Lee \& Lee, 2019). In that case, this is the third challenge: how IDLE practitioners can educate the community that the IDLE has the same potential and benefit as formal learning. It is essential to be sure that their children will get the same result either from formal or informal learning. 


\section{The technical challenges}

There is a respondent who said a thing that we considered as technical challenges. This is taken from the statement of Respondent 9. Even though he was the only one who said such a statement, we believed this issue might represent the largest problem faced by digital learning practitioners. Within this regard, he talked about the internet connectivity issue, which still unstable. He said: "...in Indonesia, the challenge more likely about the lagging, the internet connection is so slow..." (Respondent 9. Interview. July 20 2020)".

The last issue is the biggest one that needs to be faced by the informal digital learning community. Not only the internet connectivity matter, but also the technological and its supportive availability equalization still needs to be solved. Many experts talk about this, which is generally discussed within the 'digital divide' topic.

Mainly, they give more attention to developing countries: Azubuike et al. (2020) examined the digital divide in Nigeria. They found that many students were constrained from some problems such as no access to electricity or devices, the internet or phone data payment, and unstable internet connectivity. Moreover, from Lie et al. 's (2020) findings, it was known that such challenges not only faced by students but also teachers: they found that teachers in Indonesia were still troubled in implementing online class by using digital media. The issues also revolved around the teachers' inability to use technology, the conventional curriculum, and the lack of teaching materials.

Regarding this one problem, the solution is not enough to rely on an informal digital learning society. This problem is fundamental and needs to be resolved by involving all parties, including practitioners, academics, technology experts, and stakeholders. It is because educational responsibilities are the obligations of scholars and all elements of society.

In summary, the discovered challenges can be seen within this table:

Table 1. The challenges of Digital games as the IDLE implementation in EFL

\begin{tabular}{ll}
\hline Categories & Challenges \\
\hline $\begin{array}{l}\text { Physical and behavioural digital games might } \\
\text { assumptions }\end{array}$ & $\begin{array}{l}\text { Issuing directly affect one's } \\
\text { physical conditions. } \\
\text { Guiding the proper gaming } \\
\text { behaviour. }\end{array}$ \\
& $\begin{array}{l}\text { Directing parents control upon } \\
\text { their children's gaming } \\
\text { activity. } \\
\text { Encountering the 'Gaming } \\
\text { Stereotype'. }\end{array}$ \\
& \\
Technical & Fulfilling the limitations of \\
& supporting utilities. \\
\hline
\end{tabular}

\section{CONCLUSION}

This research examines the challenges faced by gamer students and their activities regarding IDLE implementation in the EFL context. Respondents stated various challenges they had encountered in playing games so far. Therefore, it can be concluded that there are still some fundamental challenges that need to be faced in implementing IDLE, especially digital games, in the EFL context. We can see that most of the challenges dealt with false assumptions and negative 
opinions amongst the community regarding digital games. Naturally, things that are relatively new and not widely understood will be doubted and considered to have a harmful impact, which is experienced by digital games. Therefore, the experts' role is needed to provide information and explanations to clarify the various skewed responses. From these findings, the research supports the implementation of digital games as IDLE within an academic context by providing real pictures of regarded challenges. Various parties need to be involved in solving these challenges so that later the obtained solutions can become a holistic countermeasure. This research can also be used as a reference for practitioners and stakeholders in designing the solutions. To complete this research, future researchers can try to discuss the best options for solving these challenges.

\section{REFERENCES}

Adžić, S., Al-Mansour, J., Naqvi, H., \& Stambolić, S. (2021). The Impact of Video Games on Students' Educational Outcomes. Entertainment Computing. https://doi.org/10.1016/j.entcom.2021.100412.

Alhaq, M. N. D., Drajati, N. A., \& Tarjana, M. S. S. (2020). Self-efficacy analysis of EFL student with digital game experiences. AKSARA: Jurnal Bahasa dan Sastra, 21(1).

Ashraf, H., Motlagh, F. G., \& Salami, M. (2014). The impact of online games on learning English vocabulary by Iranian (low-intermediate) EFL learners. Procedia-Social and Behavioral Sciences, 98, 286-291. https://doi.org/10.1016/j.sbspro.2014.03.418.

Azubuike, O. B., Adegboye, O., \& Quadri, H. (2020). Who gets to learn in a pandemic? Exploring the digital divide in remote learning during the COVID-19 pandemic in Nigeria. International $\begin{array}{llll}\text { Journal of Educational } & \text { Research }\end{array}$ https://doi.org/10.1016/j.ijedro.2020.100022.

Bhargava, D., Leeprechanon, N., Rattanadecho, P., \& Wessapan, T. (2019). Specific absorption rate and temperature elevation in the human head due to overexposure to mobile phone radiation with different usage patterns. International Journal of Heat and Mass Transfer, 130, 11781188. https://doi.org/10.1016/j.csite.2020.100789.

Benson, P. \& Reinders, Hayo. (2011). Beyond the Language Classroom. New York: Palgrave Macmillan. 7.

Dong, C., Cao, S., \& Li, H. (2020). Young children's online learning during COVID-19 pandemic: Chinese parents' beliefs and attitudes. Children and Youth Services Review, 118, 105440. https://doi.org/10.1016/j.childyouth.2020.105440.

Entwistle, G. J., Blaszczynski, A., \& Gainsbury, S. M. (2020). Are video games intrinsically addictive? An international online survey. Computers in Human Behavior, 112. https://doi.org/10.1016/j.chb.2020.106464.

Fernández, C., de Salles, A. A., Sears, M. E., Morris, R. D., \& Davis, D. L. (2018). Absorption of wireless radiation in the child versus adult brain and eye from cell phone conversation or virtual reality. Environmental research, 167, 694-699. https://doi.org/10.1016/j.envres.2018.05.013

Hirschel, R., \& Fritz, E. (2013). Learning vocabulary: CALL program versus vocabulary notebook. System, 41 (3), 639-653. https://doi.org/10.1016/j.system.2013.07.016.

Jackson, C., Vynnycky, E., Hawker, J., Olowokure, B., \& Mangtani, P. (2013). School closures and influenza: systematic review of epidemiological studies. BMJ open, 3(2). http://dx.doi.org/10.1136/bmjopen-2012-002149.

Johnson, B., \& Christensen, L. (2019). Educational Research: Quantitative, Qualitative, and Mixed Approaches. Sage.

Lai, C., Ni, R., \& Zhao, Y. (2012). Digital games and language learning. Contemporary ComputerAssisted Language Learning. London: A\&C Black.

Lee, J. S. (2019a). Informal digital learning of English and second language vocabulary outcomes: 
Can quantity conquer quality?. British Journal of Educational Technology . 50 (2). 767-778. https://doi.org/10.1111/bjet.12599.

Lee, J. S. (2019b). Quantity and diversity of informal digital learning of English. Language Learning \& Technology, 23(1), 114-126. https://doi.org/10125/44675.

Lee, J. S., \& Drajati, N. A. (2019). Affective variables and informal digital learning of English: Keys to willingness to communicate in a second language. Australasian Journal of Educational Technology, 35(5), 168-182. https://doi.org/10.14742/ajet.5177.

Lee, J. S. \& Hsieh, J. C. (2019). Affective variables and willingness to communicate of EFL learners in in-class, out-of-class, and digital contexts. System. $82.63-73$. https://doi.org/10.1016/j.system.2019.03.002.

Lee, J. S. \& Lee, K. (2019). Informal digital learning of English and English as an international language: The path less traveled. British Journal of Educational Technology. 50 (3). 14471461. https://doi.org/10.1111/bjet.12652.

Lie, A., Tamah, S., M., Gozali, I., Triwidayati, K., R., Utami, T., S., D., \& Jemadi, F. (2020). Secondary school language teachers' online learning engagement during the Covid-19 pandemic in Indonesia. Journal of Information Technology Education: Research, 19, 803-832. https://doi.org/10.28945/4626

Oyedotun, T. D. (2020). Sudden change of pedagogy in education driven by COVID-19: Perspectives and evaluation from a developing country. Research in Globalization, 2, 100029. https://doi.org/10.1016/j.resglo.2020.100029

Peterson, M. (2016). Computer Games and Language Learning. New York: Palgrave Macmillan.

Shi, J., Renwick, R., Turner, N. E., \& Kirsh, B. (2019). Understanding the lives of problem gamers:

The meaning, purpose, and influences of video gaming. Computers in Human Behavior, 97, 291-303. https://doi.org/10.1016/j.chb.2019.03.023.

Sintema, E. J. (2020). Effect of COVID-19 on the Performance of Grade 12 Students: Implications for STEM Education. Eurasia Journal of Mathematics, Science and Technology Education, 16(7), em1851. https://doi.org/10.29333/ejmste/7893.

Sundqvist, P. (2011). A possible path to progress: Out-of-school English language learners in Sweden. Beyond the language classroom (pp. 106-118). Palgrave Macmillan, London. https://doi.org/10.1057/9780230306790_9.

Syauqi, K., Munadi, S., \& Triyono, M. B. (2020). Students' Perceptions toward Vocational Education on Online Learning during the COVID-19 Pandemic. International Journal of Evaluation and Research in Education, 9(4), 881-886. http://doi.org/10.11591/ijere.v9i4.20766.

Unwin, T, Sumisra, R. G., Galvez, P., \& Stefan, V. (2020, November 12). Learn from Home During COVID-19 [Workshop session]. Internet Governance Forum 2020, Online Conference. https://www.intgovforum.org/multilingual/content/igf-2020-ws-212-learn-from-homeduring-covid-19\#undefined 